\title{
2.2 Australia: from central electricity to solar/storage systems
}

\author{
Helen Poulter
}

\subsubsection{Introduction}

Australia has one of the best solar resources in the world and also some of the highest electricity prices. It also has the highest per capita of domestic solar PV installations worldwide, at almost 25 per cent of households. In September of 2016, South Australia experienced severe storms which led to a state-wide blackout and prompted a review of the governance of the National Electricity Market (NEM). A heatwave in February 2017 caused the NEM to cut power to 90,000 of its domestic customers. This load shedding event prompted a further peak in the installation of behind-the-meter distributed generation and enquiries for domestic storage.

This chapter will give an overview of the NEM in Australia, the renewable energy resources, the current situation regarding distributed energy, and the future plans for the governance of the NEM.

\subsubsection{The Australian electricity framework}

Australia's electricity networks are separated into three regional markets and one state owned system. The NEM is the largest and operates in Eastern Australia, covering five interconnected state-based networks and is the focus of this chapter. The three other smaller systems operating in the western and northern states (The Wholesale Electricity Market (WEM), the Northern Territory Electricity Market (NTEM), and the North Western Interconnected System (NWIS)) operate under different rules to the NEM and as such will not be

\section{How to cite this book chapter:}

Poulter, H. 2020. Australia: from central electricity to solar/storage systems. In: Burger, C., Froggatt, A., Mitchell, C. and Weinmann, J. (eds.) Decentralised Energy - a Global Game Changer. Pp. 25-46. London: Ubiquity Press. DOI: https://doi.org/ 10.5334/bcf.c. License: CC-BY 4.0 
covered here. The NEM is governed and regulated by a central federal system. This section will give a brief overview of the governance institutions of the NEM and its market operation.

\section{Federal departments}

\section{Council of Australian Governments}

The Council of Australian Governments (COAG) was initially established in 1991 to drive microeconomic reform in the energy, communications, transport, and water industries (AEMC 2014b), and to replace the Special Premiers Conferences, a similar body who met at frequent intervals to discuss matters of Commonwealth importance. The members are the Prime Minister, State and Territory Premiers, and Chief Ministers and the President of the Australian Local Government Association.

The reform of the electricity industry (the goal of which was to separate policy and regulation from industry; the restructuring of industry; and to introduce competition) resulted in the commencement of the NEM in eastern Australia in 1998 and the Wholesale Electricity Market (WEM) in southern Western Australia in 2006. Since its formation COAG's role has been to promote reforms that are of national significance and/or need the co-operation of all the state and territory governments. These reforms include themes for economic and social participation, national economic competition, sustainable living, health, and reducing the disadvantages of the indigenous people.

\section{Council of Australian Governments Energy Council}

The COAG Energy Council was established in December 2013, replacing the Standing Council on Energy and Resources (SCER) and consists of the energy and resource ministers from the Commonwealth, state and territories of Australia, and New Zealand. The council was established in response to a need for energy reforms within both the gas and electricity markets, which included energy efficiency and productivity and energy security, whilst also promoting the competitiveness of Australia's mineral and energy resources, as shown in Figure 5 (COAG Energy Council 2016).

\section{Energy Security Board}

The Energy Security Board (ESB) was established in August 2017 following a review of security and reliability of the NEM (Finkel et al. 2017). The ESB consists of the CEO from each of the Australian Energy Market Commission (AEMC), the Australian Energy Regulator (AER), and the Australian Energy Market Operator (AEMO) and an independent Chair and Deputy Chair. The function of the ESB is to provide coordination of the implementation of the reforms put forward by the Finkel Review. The ESB will also 'provide whole of system oversight for energy security and reliability to drive better outcomes for consumers' (COAG Energy Council 2017). The ESB reports directly to the COAG Energy Council. 


\section{Australian Energy Market Commission}

The AEMC was established in 2005 with the objective to 'promote efficient, reliable and secure energy markets which serve the long-term interests of consumers' (AMEC 2016). Their function is to review on possible reforms to the current regulatory and market arrangements for both gas and electricity and advise the Energy Council, in conjunction with the AER and the AEMO. This includes managing rule change requests under the National Electricity Rules (NER) and the National Electricity Retail Laws (NERL).

\section{Australian Energy Market Operator}

The AEMO is the independent energy markets and power systems operator. It is responsible for the wholesale energy markets (electricity and gas) and management of the NEM. They are a limited company with operating costs recuperated through market fees (AEMO 2016a).

\section{Australian Energy Regulator}

The AER regulates the wholesale market of the NEM in compliance with NEM legislation and rules. It works in conjunction with, and is funded by, the Commonwealth with staff, resources and facilities provided from the Australian Competition and Consumer Commission (ACCC). They are the economic regulator of the energy networks and set a maximum price for network charges in collaboration with the network service providers, which is reviewed every five years. They monitor and enforce compliance with the obligations in the Retail Law, Rules and Regulations and provide a price comparison website for retail markets for those states which are compliant under the NERL, which includes Tasmania (TAS), Australian Capital Territory (ACT), South Australia (SA), New South Wales (NSW), and Queensland (QLD) (AER 2009).

\section{Energy Consumers Australia}

Energy Consumers Australia (ECA) is a not-for-profit advocacy set up by the COAG Energy Council in 2015 and funded through AEMO to represent the long-term interests of residential and small businesses within the NEM and to provide advice on energy issues to these consumers and represent their views to the Council. They work in conjunction with stakeholders from the energy industry, energy ombudsman, government and market bodies, the research community and media (ECA 2016).

\section{National Electricity Market}

The National Electricity Market is the wholesale electricity market covering the eastern coast of Australia. It is governed by the National Electricity Rules (NER) as set out by the regulatory framework of the NEL. It has over 100 participants including generators (the majority taken by coal power plants, transmission network service providers (TNSPs), distribution network service providers (DNSPs), and market customers). 


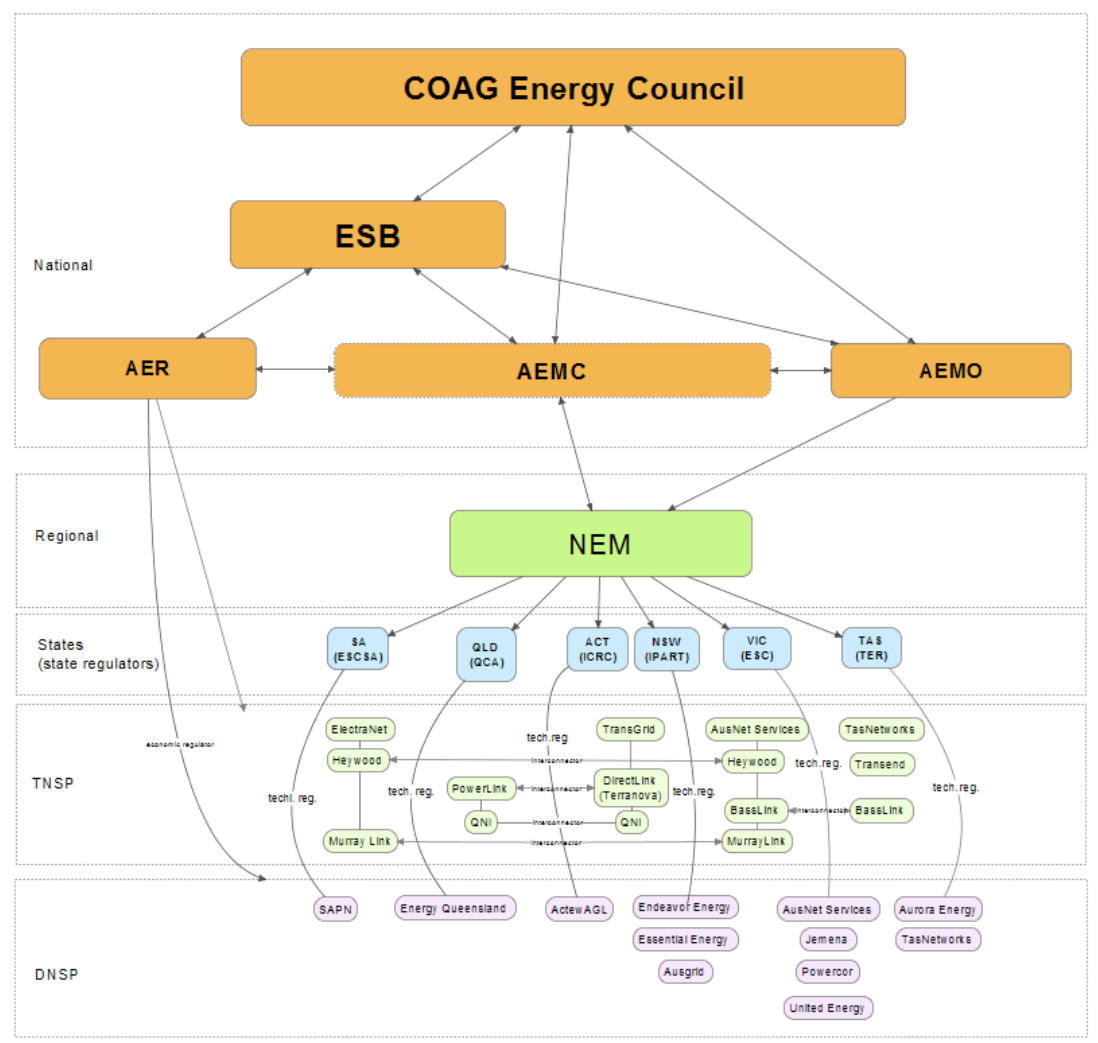

Figure 5: Electricity network governance structure of Eastern Australia.

Source: Author based in information sourced in this chapter.

The NEM is a transmission and distribution grid covering 5 interconnected state-based networks (South Australia (SA), Tasmania (TA), Victoria (VIC), New South Wales (NSW) (including the Australian Capital Territory (ACT)), and Queensland (QLD) covering a distance of approximately $5000 \mathrm{~km}$ and is operated by AEMO. It is an energy-only gross pool market with 5 minute spot prices averaged for half-hourly periods in each of the six states. Bids are taken for each of the 6 trading intervals and the averaged spot price is received by all generators dispatched in the trading interval. A recent rule change, which will take effect in 2021, is to reduce the settlement period from 30 minutes to five minutes. This change is to provide a better signal for investment into the market for new technologies and business models, such as batteries and demand response. It has been suggested that it will also reduce the 'gaming' of the half-hourly settlement by gas peaking generators and should therefore reduce prices (McConnel \& Sandiford 2016; Parkinson 2016). Risks in price volatility are reduced using hedges, options, and futures contracts (AEMO 2016c). 


\subsubsection{Australia's renewable energy resources}

Australia's renewable energy resources comprise of solar, wind, hydro, ocean, and bioenergy. Australia has the highest solar irradiation of any continent and average wind speeds in the southern part of the continent in excess of $6 \mathrm{~m} / \mathrm{s}$ (the minimum average wind speed used in assessing wind farm potential). Due to the presence in the south of a westerly wind known as the 'roaring forties', wind farms in South Australia have reported capacity factors of, on average, 33 per cent. The excellent solar resource is able to produce capacity factors of around 30 per cent in summer and 15 per cent to 18 per cent in winter (AEMO 2016c). The high potential of these resources has meant that new renewable installations (Tasmania installed its first hydropower station a century ago) have been predominantly wind and solar.

By the end of June 2018, installed capacity, including operating and underconstruction facilities of large-scale wind and solar had reached $7565 \mathrm{MW}$ with a further $774 \mathrm{MW}$ of projects signing power purchase agreements (Clean Energy Regulator 2018). Small-scale PV (systems under $100 \mathrm{~kW}$ ) split into two categories currently have:

- commercial systems (10-100 kW) of 1063 MW installed capacity

- residential systems (under $10 \mathrm{~kW}$ ) of $5556.8 \mathrm{MW}$ of installed capacity (APVI 2018a). ${ }^{4}$

In 2017-18 Australia had 44.8 GW of electricity generation capacity (AER 2019). Small-scale distributed solar now makes up 14.8 per cent of installed capacity.

\subsubsection{Distributed Renewable Generation in Australia}

The quality of the solar resource, falling prices for PV and storage, and high electricity prices have made self-generation an excellent proposal for residential and business consumers in Australia. Since 2008, the NEM states have offered their own version of feed-in-tariffs, and this, in conjunction with the Smallscale Renewable Energy Scheme, has led to the current size of the domestic market. This section will look at this in more detail.

\section{Solar schemes in the NEM}

In 2008 as part of their own renewable energy targets, and to encourage early adopters at a household and commercial level, each of the Australian states introduced their own incentives for small-scale solar $(<100 \mathrm{~kW})$. These state designed schemes were a Solar Bonus Scheme (SBS) in New South Wales

${ }^{4}$ Animation for PV installations from 2007-2018 can be found at http://pv-map.apvi. org.au/animation. 
Table 2: FiT rates for NEM states (2017).

\begin{tabular}{|l|l|l|l|}
\hline STATE & Scheme & Rate c/kWh & Max size \\
\hline Queensland & $\begin{array}{l}\text { South-eastern QLD: } \\
\text { no minimum } \\
\text { Rural QLD: } \\
\text { mandatory minimum }\end{array}$ & $\begin{array}{l}\text { Based on retailer } \\
\text { competition } \\
6-8\end{array}$ & $5 \mathrm{~kW}$ \\
\hline New South Wales & $\begin{array}{l}\text { Recommended } \\
\text { benchmark range for } \\
\text { retailers }\end{array}$ & $11.6-14.6$ & $\begin{array}{l}\text { Depends on } \\
\text { retailer }\end{array}$ \\
\hline $\begin{array}{l}\text { Australian Capital } \\
\text { Territory }\end{array}$ & $\begin{array}{l}\text { No minimum } \\
\text { Victoria }\end{array}$ & $\begin{array}{l}\text { Depends on } \\
\text { retailer: currently } \\
6-8\end{array}$ & n/a \\
\hline South Australia & No minimum & $\begin{array}{l}11.3 \\
\text { Depends on } \\
\text { retailer: currently } \\
6-12\end{array}$ & per day \\
\hline Tasmania & Set rate & 7 & $\begin{array}{l}\text { First } 45 \mathrm{kWh} \\
10 \mathrm{~kW} \text { single phase } \\
30 \mathrm{~kW} \text { three phase }\end{array}$ \\
\hline
\end{tabular}

Source: Energy Matters (2017).

(NSW) and a Premium feed-in-tariff (FiT) in Tasmania (TAS) and the Australian Capital Territory (ACT). The SBS and Premium FiT paid between $44 \mathrm{c}$ per $\mathrm{kWh}$ and $60 \mathrm{c}$ per $\mathrm{kWh}$ dependent on state regulated tariffs for all $\mathrm{PV}$ generated electricity. South Australia (SA) and Queensland (QLD) had a net FiT which paid 44-60 per kWh for electricity that was fed back into the grid. All state schemes were initially open to unlimited size of domestic system but then curtailed to $5 \mathrm{~kW}$. In 2012, the schemes closed to new entrants and the tariff reduced to around $8 \mathrm{c}$ per $\mathrm{kWh}$. Those whose systems were registered and installed before the 2012 deadline would receive the initial Premium or Net FiT or SBS until 2028. Future FiTs will be set and paid by the retailer with no minimum requirement but with the states able to set minimums or provide benchmark ranges as a guide for retailers if they wish (Table 2).

\section{The small-scale renewable energy scheme}

In 2011 the Small-scale Renewable Energy Scheme (SRES) was introduced as a measure to encourage individuals and small businesses to invest in eligible renewable energy (RE) systems (CER 2018). The scheme will run until 2030. SRES certificates are produced for new renewable generation by solar PV, wind, or hydro and for the energy displaced by a solar water heater or heat pump over the course of a designated period. The certificates can be generated by 
the owner of the eligible technology or by an installer who has been assigned the right to generate the certificate by the owner. As one certificate is equal to $1 \mathrm{MWh}$, small-scale renewable energy (RE) installers can aggregate smaller RE systems to reach the $1 \mathrm{MWh}$ target and pass on savings to the customer. The certificates are sold to energy retailers, who are required to surrender an amount of certificates each year, through a spot market or through a Government Clearing House (RET 2018). The value of the certificates is dependent on the spot market price, currently Aus $\$ 35.50 / \mathrm{MWh}$. Alternatively, certificates can be traded through the government Clearing House at Aus $\$ 40 / \mathrm{MWh}$. Certificates will only be traded through the Clearing House if there are no certificates available through the spot market. The added benefit of the scheme is that it gives the AEMO visibility of the location and density of behind-the-meter RE which allows for better forecasting for grid demand.

\section{The rise of DER in Australia}

During the years between 2010 and 2012, Australia saw a huge uptake of distributed solar PV with 900,000 of the current 1.7 million systems being installed in those three years (Figure 6).

This led to the highest percentage penetration rates of domestic PV systems worldwide, double that of Belgium and three times that of Germany and the United Kingdom (AEC 2016), as shown in Figure 7.

The result of this uptake has meant that in SA there has been a shift in the time of operational peak demand as the capacity of residential PV systems

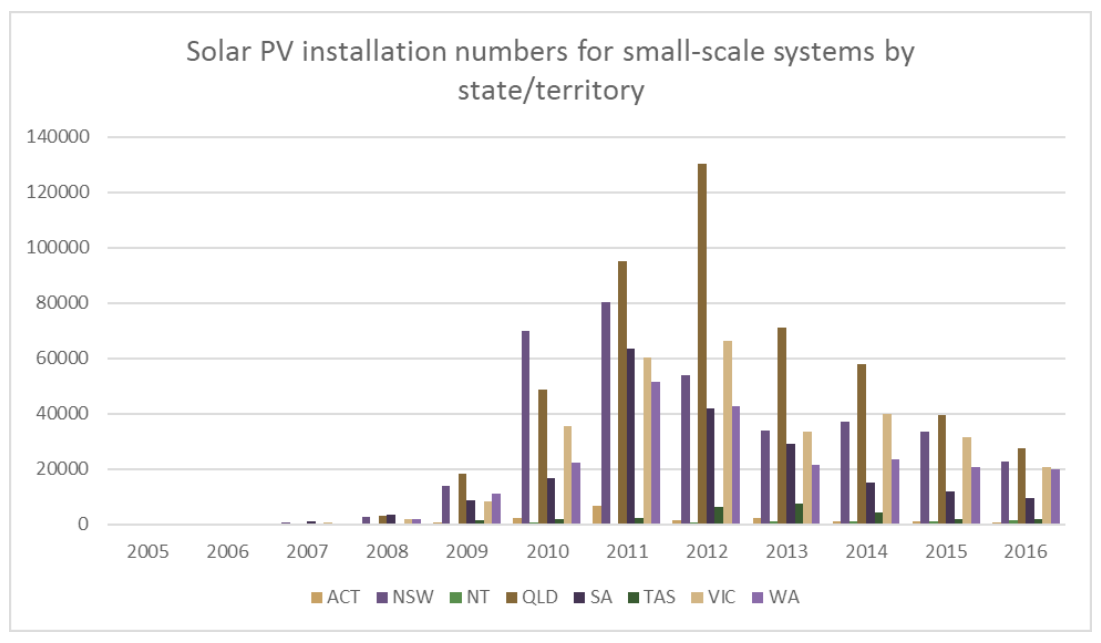

Figure 6: Number of domestic solar PV systems installed by year in the NEM states.

Source: Clean Energy Regulator (2016). 


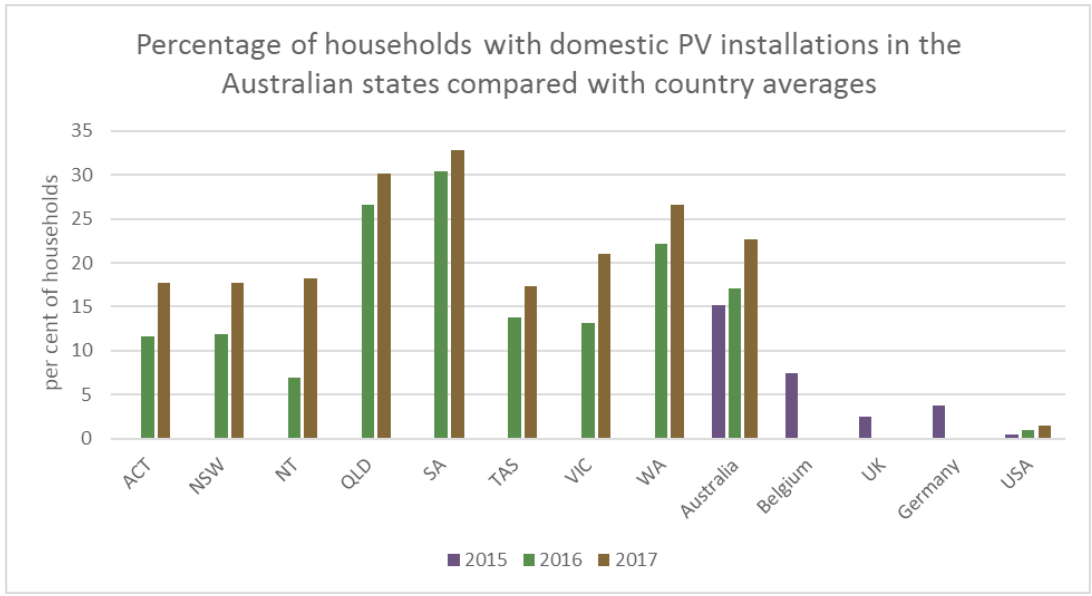

Figure 7: Comparison of state/territories of Australia at year end 2016 (Clean Energy Regulator 2016), end of May 2017 (Roy Morgan Research 2017) and world averages in 2015.

Source: AEC (2016).

(679 MW) reduced the daytime peak demand profile by almost 10 per cent in 2015-16 (AEMO 2016c), producing what is now being called a 'duck-curve'. In its National Electricity Forecasting Report (AEMO 2016a), AEMO (the market operator) predicts a reduction and flattening of consumption for grid supplied electricity due to further uptake of PV from both business and residential customers, and an increase in the energy efficiency of households and appliances. It also recognises that maximum demand for generated power will continue to shift to both later in the day and year, towards the Australian winter evenings. This shift has led to a reduction for demand in baseload power but an increase in demand for peaking plants.

Australia has been the obvious choice for the introduction of residential storage due to its dominance of the rooftop PV market. In 2016, companies competing for this market included Tesla, Enphase, GCL Poly, Sonnen, and RedFlow, with Tesla launching its new Powerwall 2.0 energy storage device at a cost to Australian consumers of Aus $\$ 0.23 \mathrm{kWh}^{-1}$ (Peacock 2016). In some states of the NEM it is now, and will be in the future, cheaper to install, generate, and store electricity than to buy retail and, dependent on pricing structures, be grid connected e.g. retailers are now charging a standing rate for meters which is between 80 and 150 c per day or between Aus $\$ 292$ and Aus $\$ 547.50$ per year with the average price for installing a $5 \mathrm{~kW}$ PV array plus storage cAus $\$ 16,000$ (Mountain 2016).

In Figure 8, the cost of the PV/storage system in the NEM states has been calculated for a 10 year lifetime (the average lifespan of a battery system), however, 


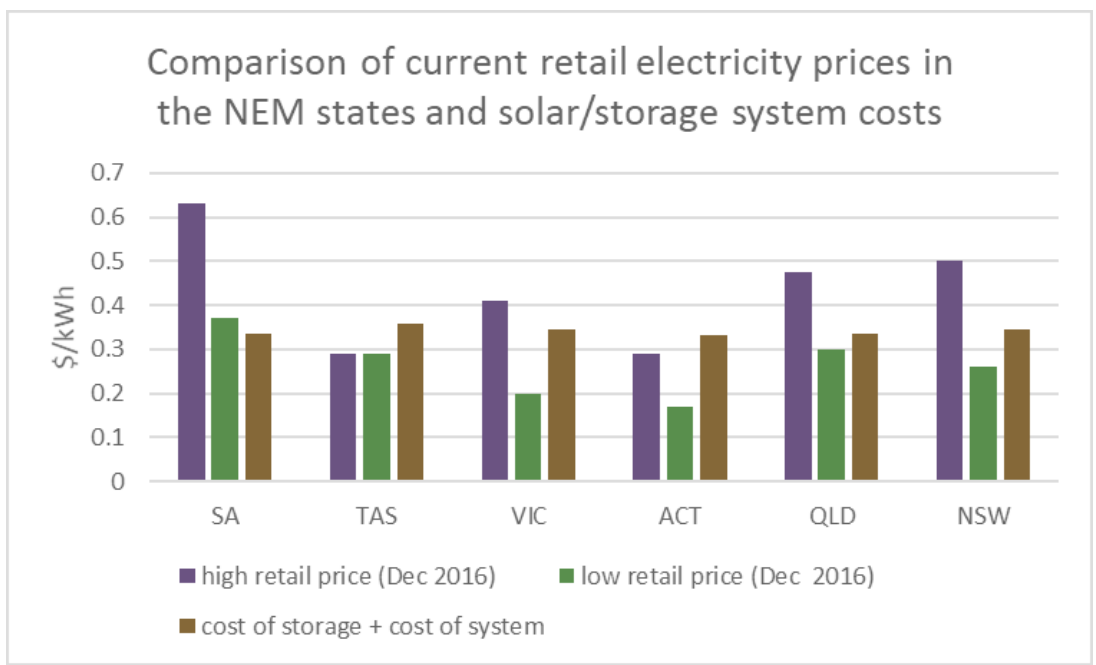

Assuming lifespan of 10 years for both (after 10 years costs drop to Aus $\$ 0$ ), costs for PV taken from solar choice.net.au and solar resource and household electricity use for each of the capital cities calculated for each of the NEM states. As it is assumed that these households would not use the grid, no allowance has been made for FiT payments

Figure 8: Cost of a solar/storage system.

Source: Australian Government (2017), Peacock (2016), Solar Choice (2017).

if costs were to be spread over a 20 year lifetime, QLD and TAS would also see DER costs cheaper than retail prices. These figures do not include government FiT schemes in order to indicate the cost of the system assuming the customer wanted to disconnect from the grid. In AEMO's South Australian Electricity Report (AEMO 2016b), with figures based on information available until July 2016, expected uptake of combined PV and storage systems was predicted to begin slowly and not see growth until after 2020. It also predicted that retrofit of storage systems would be uneconomical. However, nationally in 2016, 6750 storage units were installed, up from the previous year's figure of 500, and this with no government or policy support. It was estimated that in 2017 , due to the late arrival of the Powerwall 2.0 and new technology that would ease the retrofitting and installation of storage units, that Australia would install as many as 20,000 domestic scale units (Morris 2017). A report from the Clean Energy Council (Clean Energy Council 2018) using figures from SunWiz has now stated that the current number of installations (as at the end of 2017) stands at 28,000 with 12 per cent of installations in 2017 also incorporating storage, up from 5 per cent the previous year.

After the commencement of the NEM the real term cost of retail electricity fell until 2007. In 2010-12 there was steep rise with various factors combining causing this rise i) a growth in peak demand requiring new infrastructure and 
generating capacity, ii) retirement of old coal thermal plant, and iii) switching to gas generation for peaking plants and baseload power at a time when global gas prices were increasing (Simshauser \& Laochumnanvanit 2011).

Forecasts had predicted an increase in electricity demand which would require new infrastructure and generating capacity. In fact demand fell which meant that electricity companies invested in unneeded infrastructure (Saddler 2017). The incorrectly forecast increase in demand meant that the electricity networks augmented their power lines for an expected increase in a one-way flow of energy. These investments then formed part of the networks regulated asset base (RAB). The return on these investments accounts for more than half of the network businesses total revenue. This high revenue and hence a continuing high RAB leads to high network charges for consumers. In Australia the network charges currently make up around 40 per cent of customers' bills.

Old coal thermal power plants were retired and replaced with combined cycle gas thermal power plants (CCGT). At this time there was an increase in global gas prices which led to the development of 3 LNG export projects in Queensland. These developments limited the availability of local gas for the domestic market and caused wholesale gas prices to rise, affecting the cost of electricity supplied by gas generation in the NEM (Oakley Greenwood 2016) and therefore increasing prices for consumers. Forecasts predict more increases for residential electricity prices in 2020, between 15 and 20 per cent higher than 2016 levels.

Future price rises have been attributed to a reliance on gas for future electricity supply and an unexpected reduction in electricity demand leading to over-investment in generation capacity (Reed 2016). In particular South Australia (SA) and Queensland (QLD) are more reliant on gas generation for baseload power. It is forecasted that commercial and industrial users could see increases of 20-40 per cent compared to 2016 levels by 2037 (Parisot \& Nidras 2016).

For domestic customers the retail cost of electricity is made up of two separate charges, a daily supply charge, between 80 and $150 \mathrm{c}$ per day dependent on state and supplier, and the volumetric charge, which includes costs for distribution, transmission, retail, and wholesale costs, and environmental policies. On 1st July 2016 the network prices in the ACT and NSW increased, but decreased in QLD, SA, and TAS (Duffy \& Johnston 2016) therefore the rise in retail prices seen in the latter states could be attributed to an increase in generation costs and/or environmental policies, or due to the reduction in volume of sales from customers.

Following the continuing price rises the Australian Competition and Consumer Commission (ACCC) released a report on retail pricing in the NEM (ACCC 2018). The report recognises that competition in the NEM is not working and that the current approach to policy, regulatory design, and promotion of competition is not working in the best interests for consumers. The report has 56 recommendations around four broad areas: 
1. Boosting competition in generation and retail.

2. Lowering costs in networks, environmental schemes and retail.

3. Enhancing consumer experiences and outcomes.

4. Improving business outcomes.

\subsubsection{Disruption within the electricity industry}

There has been both climatic and technological disruptions within the electricity industry in Australia. Climatic disruption resulting in blackouts (as a result of extreme heatwaves), and technological disruption - the unprecedented penetration of DER, causing some commentators to suggest that Australia may be soon in the grips of a utility 'death spiral'.

\section{Box 1: Climatic events}

On the 28th September 2016 storms in northern South Australia, including tornados with wind speeds in the range of $190-260 \mathrm{~km} / \mathrm{h}$ caused a state-wide blackout. The update report (AEMO 2017b) from AEMO and also a recent review by the Chief Scientist, Alan Finkel (Finkel et al. 2017) have recommended that value services for Frequency Controlled Ancillary Service (FCAS) and System Restart Ancillary Services (SRAS) from distributed energy and other storage technologies should be investigated.

In addition, on February 8th 2017 , a heatwave with temperatures of $41.6^{\circ} \mathrm{C}$ left 90,000 homes (AEMO 2017c) in South Australia without power as AEMO committed to load shedding due to failures of its fossil fuel generators. The demand forecasts they had received had not anticipated the cooling demand for the period and the reduced wind power due to a drop in wind speed. A $165 \mathrm{MW}$ gas plant was 'unavailable' and unable to startup in the time requested, needing 4 hours notice, leaving homes without power in the evening on one of the hottest days of the summer.

\section{The 28th September 2016 events in detail:}

- The northern South Australia Storms, including tornados with wind speeds in the range of 190-260 km/h, caused multiple network faults and downed 3 major transmission lines;

- the resulting voltage disturbances caused settings on the wind generators to reduce their output; 
- a necessary increase in imports through the Heywood interconnector from Victoria caused a loss of synchronism and led to one of the interconnectors tripping;

- the FCAS capability of the gas generators - which should have stopped a collapse of system frequency was unable to respond at the required speed;

- the SRAS - which also should have stopped a collapse of system frequency - were unable to start due to unexplained failures;

- this led to a collapse of electricity system frequency.

These two events happened in an Australian state which has over 30 per cent of households with rooftop PV and in which installing combined domestic scale solar and storage is cheaper than buying grid electricity. As can be seen from Figure 12 there has been a 5.5 per cent rise in the number of domestic PV installations in the first half of 2017 which has been attributed in some way to these events.

\section{The death spiral effect}

A death spiral is a positive feed-back loop. This occurs when, due to rising network charges within electricity prices, consumers switch to their own onsite generation and/or leave suppliers. This then leaves the initial network company supplier with either less customers or less $\mathrm{kWh}$ from which to recoup costs thus having to raise prices, and so on, until demand eventually collapses. Within energy this phenomenon has been recognised as a utility death spiral.

The term 'utility death spiral' saw a re-emergence recently in Australia. The term was originally coined with the new era of competition as energy markets opened up and the rising costs of some utilities meant that consumers could switch to cheaper alternatives/sources (Costello \& Hemphill 1990). Then, it was much more a conceptual argument - a threat - to ensure policies which did not lead to a death spiral. A perfect storm of requirements would be needed to induce such a spiral - inflexible pricing structures, large defections and the utilities unable to change their behaviour (Graffy \& Kihm 2014). Increasingly, the possibility of consumers generating and storing their own power and adding in a new type of disruptive competition has added to the potential drivers for a death spiral.

As can be seen from the current situation in Australia, the combination of a high percentage of householders already with PV installed, access to cheap storage, and high priced retail electricity means that the Australian electricity markets could be experiencing the beginnings of a death spiral which could threaten the existing incumbents. 
Utility costs - those for network charges currently make up 40-50 per cent of the Australian retail price (AEMC 2016), in comparison to the United Kingdom, where network costs are approximately 27 per cent (Ofgem 2017). There are high retail costs currently and further rises expected in the future, which will invariably mean that the rate of return for the customers installing DER systems will be favourable. In response to this, and the need to reduce the percentage of the retail charge for network costs, retail companies include a standing charge (average Aus $\$ 400$ per year) for domestic customers as well as the volumetric charge. It is now affordable for domestic customers to generate and store the majority of their electricity needs (Mountain 2016). If a larger and larger percentage of people install DER, so a smaller proportion of grid-generated electricity is needed. Should storage costs continue to fall, and domestic generators not given value for their contribution to decarbonising the energy system, disconnecting from the grid may become a viable choice for Australian householders. This suggests that, if Australia wishes to limit the possibility of a death spiral for its utilities, it will need to create value for DER for both the utilities and the consumer. Certainly, continuing in its current position is widely recognised as not an option.

\subsubsection{The future of the Australian electricity system}

Australia is in a unique position as high electricity prices, falling costs for DER, and issues concerning the reliability of electricity supply has caused, as of 2017, just over a quarter of households to install solar PV. There has also been significant rises in larger $(50-100 \mathrm{~kW})$ installations for business and small commercial properties (APVI 2018b). The threat of a possible death spiral for utilities and the increase in frequency and ferocity of climatic events, as predicted for anthropogenic climate change, have highlighted the need for a more reliable and flexible grid; and a market which rewards DER - something that Australia does not have currently. AEMO (the market operator) has recently appointed Audrey Zibelman, ex Commissioner of the New York (NY) Public Service Commission in New York state (NYS), United States, as the new Head of AEMO. Ms Zibelman was the driver of the NYS's progressive market and network regulation known as the NY Reforming the Energy Vision (REV) (Mitchell 2016), and one can expect therefore similar ideas as those set out in the NY REV to occur in Australia. In a recent interview (ABC Radio 2017) Audrey Zibelman explained how Hurricane Sandy caused New York to rethink its energy strategy. She also talked of the implementation of a solar-based micro-grid in Brooklyn and said she hopes to see such schemes, of which there are a few being trialled within the Australian electricity markets, soon being an integral part of the new energy system in Australia.

In December 2017, following AEMO's (and particularly Ms Zibelman's) support of trialling demand response to alleviate extreme demand peaks during high 
summer temperatures (AEMO 2017a), the AER commenced a Demand Reduction Incentive Scheme and Innovation Allowance Mechanism (AER 2017). The Incentive is targeted at the distribution companies to use non-network solutions to provide reduction in demand and the Mechanism provides a small amount of funding for R\&D in demand management projects. There is also an allowance (Aus $\$ 200 \mathrm{~K}$ ) to help with the roll out of any innovation projects. One trial has been for a community-based pilot project, Power Changers (Jemena 2018). The trial is being led by Jemena, one of the Victorian distribution companies. The project uses an app to encourage users to complete challenges to reduce their demand. If the challenges are completed, they receive reward points. These reward points are then collected and converted into a monetary reward given to an organisation chosen by the community, such as a school.

The NEM also has the problem of many rural customers at the end of long, thin distribution wires. In some cases these wires can extend, over terrain with a high bush fire risk, for $100 \mathrm{~km}$ to serve just a handful of customers. The costs of maintaining this wire are exorbitant and, as all network costs are spread over all consumers; microgrids would enable a more reliable service for rural customers and an overall reduction in customer bills. Although an excellent solution, there are problems arising from this for a privately owned, competitive market such as the NEM. The question currently being examined is how to introduce competition for retail, generation, and storage in micro-grids whilst ensuring consumer protections

In the NEM the big 3 'gentailers' - Origin Energy, AGL, and EnergyAustralia have been encouraging the use of battery systems by offering PV and battery packages through their retail services. Although this seems contrary to what would be expected from fossil fuel generating companies, it shows that some of the Australian generators are accepting that the future energy system will need to include a large proportion of DER and are therefore already deciding to enter the field.

As well as offering a residential and commercial storage package, AGL are trialling a Virtual Power Plant (VPP) in Adelaide, SA (AGL 2017). The VPP is made up of 1000 domestic solar PV and battery systems which are aggregated and so can be seen on the network. These can then be used for network services such as peak demand reduction and frequency control. This will help to create resilience for the network and reliability for the consumer. A similar scheme is also underway in Bruny Island, Tasmania. Reposit Power in collaboration with the Australian Renewable Energy Association (ARENA), TasNetworks, and academia in Melbourne and Tasmanian Universities, have set up a VPP to reduce the islands reliance on back-up diesel generation (Reposit Power 2017).

In 2017 in SA the previous Labor government and Tesla began a trial of a VPP of 50,000 homes. The initial trial installed $5 \mathrm{~kW}$ of rooftop solar and a 15.3 kWh Tesla Powerwall battery on 100 housing association homes. This trial is the first stage which will see another 1000 homes with solar and batteries installed in the second stage. The original trial was then to extend this to a total 
of 50,000 homes in a third stage. However, after a recent change of government it is expected that this will change to the election promise of Aus $\$ 100 \mathrm{~m}$ of grants towards domestic battery storage, an estimated 40,000 homes. The new government has still shown an interest in the Tesla proposal and is also interested in other battery companies such as Sonnen and is promising that SA will still lead the way in renewable energy transformation (Parkinson 2018).

Due to the rise in DER there has also been the question of tariff reform to reduce the 'death spiral' effect and increase visibility of DER. One idea being spoken about is to change from a kWh charge to a kWp (kilowatt peak) charge. This tariff would be similar in effect to a mobile phone data plan. The customer would choose a plan based on their peak kilowatt usage e.g. not going above 3 $\mathrm{kW}$ of demand at any one time. If they go over this limit they would have to pay a fee. They would then be given the option to increase their plan if they thought that this would be something that would happen often e.g. they install an air conditioner which uses energy when their PV system is not generating or charge an electric vehicle at peak times. This would then give the customer the option of (1) changing their consumption patterns, (2) changing to a new plan, or (3) buying energy storage dependent on the economics and/or customer preferences. The idea behind this is that high costs for the consumer come from the need for peaking generators and distribution capacity to cover these peaks. By customers committing to a peak level this will give the distribution companies and the market operator visibility of where, and how much, generation and network capacity is needed.

\section{The Finkel Review}

Following the events of September 2016 the federal government undertook a review of the governance of the NEM. The review was undertaken by the Office of Australia's Chief Scientist - Dr Alan Finkel. The review 'An Independent Review into the Future Security of the National Electricity Market: Blueprint for the Future' (Finkel et al. 2017) made recommendations on the themes of:

- increased energy security within the NEM for increased penetration of variable renewable resources, including valuing frequency response, synthetic inertia, demand response, and voltage control and also cyber security due to the increase of IT services within the system;

- policy stability with recommendations for a long ranging Clean Energy Target (CET) which would see certificates issued for all types of generation with more certificates issued for the least polluting technologies;

- efficiency within the gas markets to ensure that electricity generators are able to maintain reliability of supply;

- improved system planning to include a transmission and distribution plan to recognise areas of future economically viable VRE penetration, also a review of regulation to remove the incentives for networks to prioritise over non-network solutions; 
- rewarding consumers including the facilitation of a DER market and a change in role for the distribution networks to provide a platform for new technologies;

- stronger governance to include the establishment of an Energy Security Board (ESB) to oversee the implementation of the plan and to be a single point of responsibility and accountability between market institutions and the Energy Council. This area will also review the rule-change process to accommodate the rapidly changing energy market.

In total there were 50 recommendations contained within the main points above. In July 2017 the review was presented to the COAG Energy Council for approval and 49 out of the 50 recommendations were approved. The council felt that the Clean Energy Target would need further consideration.

The Energy Security Board was appointed in September 2017 and announced plans at the end of 2017 for a National Energy Guarantee (NEG). The NEG will combine a Reliability Guarantee and an Emissions Guarantee. In order for the policy to take effect, it will need approval from all members of the COAG Energy Council. Following consultation in April 2018 the final version of the NEG will be published in August 2018 (note that, following a review by the Energy Council, the NEG has not been approved and Australia currently has no energy policy post 2020).

Following the Finkel Review recommendations AEMO have released their Integrated System Plan (ISP) (AEMO 2018). The plan recognises that there are fundamental changes happening within the Australian energy system:

- flattening of grid demand due to the rise in behind the meter DER and energy efficiency (even assuming a rise in EV ownership);

- the coal power stations that currently provide the majority of power are due to be retired in the next 20 years;

- the costs and capabilities of new supply resources have changed significantly and are expected to do so in the future;

- renewables, storage technologies, and flexible gas-powered generation are expected to be the core components to a low cost and reliable energy future.

In order to incorporate renewables, both at grid scale and at domestic scale, the Integrated System Plan makes recommendations for increased interconnection between the states, investment into Renewable Energy Zones (REZ), and coordination of behind the meter DER. AEMO and Energy Networks Australia (ENA) have also released a consultation paper on 'how best to transition to a two-way grid that allows better integration of Distributed Energy Resources for the benefit of all customers' (AEMO \& ENA 2018). AEMO and the ENA have given possible frameworks for integrating DER:

a. a single integrated platform where the market operator provides a central platform in which all distribution level actors are able to participate; 
b. a two-step tiered platform in which the DNOs are responsible for optimisation and DER dispatch within their own network areas;

c. an independent distribution service operator (DSO) or AEMO optimising distribution level dispatch which would involve either an overarching iDSO or multiple iDSOs at the individual network level.

Within the report the agencies recognise the value that DER could bring if given an effective framework in which to operate. This is in comparison to a lack of coordination which would increase costs for everyone.

\subsubsection{Conclusion}

2018 saw the beginning of many changes to the Australian electricity system with the COAG Energy Council agreeing to implement 49 out of the 50 recommendations made by the Finkel review, in particular the replacement of the current Renewable Energy Target with the controversial National Energy Guarantee. For DER the Finkel review includes giving value to customers for demand management, changing the role of the distribution networks to facilitate a DER market and a review of network regulation. Should the NEM governance institutions follow the advice given within the review, then this will help to avoid new network costs and promote alternative non-network solutions which will enable all customers to benefit from a flexible, low-emission electricity system.

Australia is experiencing particular governance issues due to the disruption caused by the rapid increase in DER and the effect of this on a huge interconnected transmission grid such as the NEM. A new system operation which offers a cost-effective solution to both these challenges can be provided by DER, and we can expect - given the Finkel Review, the acceptance of DER by some of the utility companies, and Audrey Zibelman's new appointment - that this is where the momentum is within Australian system operation.

\section{Author's note}

A small amount of the above chapter was previously published by the author on the IGov New Thinking for Energy blog, found at http://projects.exeter.ac.uk/ igov/new-thinking-tales-of-the-unexpected/

\subsubsection{References}

ABC Radio. (2017), Audrey Zibelman interview. Retrieved July 18, 2017, from http://mpegmedia.abc.net.au/rn/podcast/2017/04/sea_20170401_0745.mp3 ACCC. (2018), Restoring electricity affordability and Australia's competitive advantage: retail electricity pricing inquiry-final report, Canberra. Retreived 
July 23, 2018, from https://www.accc.gov.au/system/files/Retail Electricity Pricing Inquiry-Final Report June 2018_Exec summary.pdf

AEC. (2016), Renewable energy in Australia - how do we really compare?, Australian Energy Council. Retreived February 10, 2019, from https://www. energycouncil.com.au/, accessed February 10, 2019

AEMC. (2014b), National electricity market: a study in successful microeconomic reform. Retrived from http://www.aemo.com.au/About-the-Industry/ Energy-Markets/National-Electricity-Market.

AEMC. (2016), 2016 residential electricity price trends, Sydney. Retrieved August 31,2017, from http://www.aemc.gov.au/getattachment/be91ba47-45df-48ee9dde-e67d68d2e4d4/2016-Electricity-Price-Trends-Report.aspx

AEMO. (2016a), National electricity forecasting report, Australian Energy Market Operator. Retrieved from http://www.aemo.com.au

AEMO. (2016b), South Australian electricity report, Australian Energy Market Operator. Retreived from http://www.aemo.com.au

AEMO. (2016c), South Australian renewable energy report, Australian Energy Market Operator. Retrieved from http://www.aemo.com.au

AEMO. (2017a), ARENA and AEMO join forces to pilot demand response to manage extreme peaks this summer. Retrieved March 13, 2018, from https:// www.aemo.com.au/Media-Centre/ARENA-and-AEMO-join-forces-topilot-demand-response-to-manage-extreme-peaks-this-summer

AEMO. (2017b), Black system South Australia 28 September 2016, Melbourne. Retreived July 18, 2017, from https://www.aemo.com.au/-/media/Files/ Electricity/NEM/Market_Notices_and_Events/Power_System_Incident_ Reports/2017/Integrated-Final-Report-SA-Black-System-28-September2016.pdf

AEMO. (2017c), System event report South Australia, 8 February 2017, Melbourne. Retrieved July 18,2017, from https://www.aemo.com.au/-/media/ Files/Electricity/NEM/Market_Notices_and_Events/Power_System_ Incident_Reports/2017/System-Event-Report-South-Australia-8February-2017.pdf

AEMO. (2018), Integrated system plan for the national electricity market, Melbourne. Retreived July 23, 2018, from http://www.aemo.com.au/-/media/ Files/Electricity/NEM/Planning_and_Forecasting/ISP/2018/IntegratedSystem-Plan-2018_final.pdf

AEMO \& ENA. (2018), Open energy networks: consultation on how best to transition to a two-way grid that allows better integration of distributed energy resources for the benefit of all consumers. Retrieved July 23, 2018, from https://www.aemo.com.au/-/media/Files/Electricity/NEM/DER/2018/ OEN-Final.pdf

AER. (2009), appendix: energy market reform.

AER. (2017), Demand management incentive scheme, Melbourne. Retreived Januart 17, 2018, from https://www.aer.gov.au/system/files/AER - Demand management incentive scheme - 14 December 2017.pdf 
AER. (2019), Generation capacity and peak demand|Australian Energy Regulator. Retrieved from https://www.aer.gov.au/wholesale-markets/wholesalestatistics/generation-capacity-and-peak-demand

AGL. (2017), Virtual power plant - South Australia. Retreived August 5, 2017, from https://aglsolar.com.au/power-in-numbers/

APVI. (2018a), Mapping Australian photovoltaic installations, Australian Photovoltaic Institute. Retreived July 23, 2018, from http://pv-map.apvi.org.au/ historical\#4/-26.67/134.12

APVI. (2018b), PV postcode data, Australian Photovoltaic Institute. Retreived March 13, 2018, from http://pv-map.apvi.org.au/postcode

Australian Government. (2017), Find an energy plan, Energy made easy. Retreived March 13, 2018, from https://www.energymadeeasy.gov.au/

Clean Energy Council. (2018), Clean energy Australia, Melbourne. Retreived from https://www.cleanenergycouncil.org.au/resources/resources-hub/ clean-energy-australia-report

Clean Energy Regulator. (2016), Postcode data for small-scale installations. Retreived January 10, 2017, from http://www.cleanenergyregulator.gov.au/RET/Forms-and-resources/Postcode-data-for-small-scaleinstallations\#Smallscale-installations-by-installation-year

Clean Energy Regulator. (2018), Large-scale renewable energy target market data. Retreived July 23, 2018, from http://www.cleanenergyregulator.gov. au/RET/About-the-Renewable-Energy-Target/Large-scale-RenewableEnergy-Target-market-data

COAG. (2016), About COAG | Council of Australian Governments (COAG) Retrieved November 21, 2016 from http://www.coag.gov.au/about_coag

COAG Energy Council. (2017), Energy security board. Retreived March 13, 2018, from http://www.coagenergycouncil.gov.au/energy-security-board

Costello, K.W., Hemphill, R.C. (1990), Competitive Pricing In The Electric Industry*. Resour. Energy 12, 49-63.

Dufty, G. \& Johnston, M.M. (2016), The NEM - A hazy retail maze, Melbourne: Alviss Consulting. Retreived February 10, 2019, from https://alvissconsulting. com/the-national-energy-market-a-hazy-retail-maze/

ECA. (2016), Mission and vision. Retrieved September 9, 2019, from https:// energyconsumersaustralia.com.au/about-us/mission-and-vision

Energy Matters. (2017), Australian solar feed-in tariff information - Energy Matters. Retreived August 2, 2017, from http://www.energymatters.com. $\mathrm{au} /$ rebates-incentives/feedintariff/\#northern-territory

Felder, F.A. \& Athawale, R. (2014), The life and death of the utility death spiral. Electricity Journal, 27(6), 9-16.

Finkel, A., Moses, K., Munro, C., Effeney, T. \& O’Kane, M. (2017), Independent review into the future security of the National Electricity Market - blueprint for the future. Canberra. Retreived August 5, 2017, from see http:// www.environment.gov.au/system/files/resources/1d6b0464-6162-4223ac08-3395a6b1c7fa/files/electricity-market-review-final-report.pdf 
Graffy, E., Kihm, S. 2014, Does disruptive competition mean a death spiral for electric utilities? 35, 1-31.

Horizon Power. (2017a), Install solar|Buyback eligibility|Horizon Power. Retreived July 20, 2017, fromhttps://horizonpower.com.au/solar/eligibilityto-install-and-buyback-schemes/\#for-home

Horizon Power. (2017b), Onslow power project. Onslow Power Project. Retreived August 5, 2017, from https://horizonpower.com.au/our-community/ projects/onslow-power-project/

Horizon Power. (2017c), Stand-alone power systems project. Retrieved August 5, 2017, from https://horizonpower.com.au/our-community/projects/ stand-alone-power-systems-project/

Jacana Energy. (2017), Solar buyback rates. Retreived August 2, 2017, from https://jacanaenergy.com.au/photovoltaic_pv_solar_systems/solar_buy back_rates

Jemena. (2018), Power changers pilot. Retreived March 13, 2018, from http:// jemena.com.au/home-and-business/electricity/my-electricity-supply/ power-changers-pilot

Laws, N.D., Epps, B. P., Peterson, S.O., Laser, M. S. \& Wanjiru, G K. (2016), On the utility death spiral and the impact of utility rate structures on the adoption of residential solar photovoltaics and energy storage. Applied Energy. Retreived from http://linkinghub.elsevier.com/retrieve/pii/S0306261916315732

McConnell, D. \& Sandiford, P.M. (2016), Winds of change: an analysis of recent changes in the South Australian electricity market. Melbourne Energy Institute

Mitchell, C. (2016), US regulatory reform: NY utility transformation. IGov: new thinking for energy. Retreived July 18, 2017, from http://projects.exeter. ac.uk/igov/us-regulatory-reform-ny-utility-transformation/

Morris, N. (2017), Battery storage_Is Australia on track to be the world's biggest market? One step off the grid. Retreived February 8, 2017, from https:// onestepoffthegrid.com.au/battery-storage-australia-track-world-biggestmarket $/$ ?utm_source $=\mathrm{RE}+$ Daily+Newsletter\&utm_campaign $=$ afd71 aa60fEMAIL_CAMPAIGN_2017_02_08\&utm_medium=email\&utm_ term=0_46a1943223-afd71aa60f-40390089

Mountain, B. (2016), Tesla's price shock: solar + battery as cheap as grid power. RenewEconomy. Retreived September 25, 2017, from http://reneweconomy. com.au/teslas-price-shock-solar-battery-as-cheap-as-grid-power-22265/

Murgia, M. \& Thomas, N. (2017, March 12), DeepMind and National Grid in AI talks to balance energy supply, Financial Times.

Oakley Greenwood. (2016), Gas Price Trends Review.

Ofgem. (2017), Infographic: Bills, prices and profits. Retreived August 31, 2017, from https://www.ofgem.gov.uk/publications-and-updates/infographicbills-prices-and-profits 
Parisot, L. \& Nidras, P. (2016), Retail electricity price history and projections - Public. Melbourne: Jacobs Australia Pty

Parkinson, G. (2016), Change market rules, and battery storage will easily beat gas. RenewEconomy. Retreived March 13, 2018, from http://reneweconomy.com.au/change-market-rules-and-battery-storage-will-easily-beatgas-12917/

Parkinson, G. (2017a), Network limits on solar, storage could accelerate "death spiral." Reneweconomy. Retreived April 6, 2017, from http://renew economy.com.au/network-limits-on-solar-storage-could-accelerate-deathspiral-65424/

Parkinson, G. (2017b), States threaten to go it alone on clean energy as Coalition loses plot. RenewEconomy. Retreived July 13, 2017, from http:// reneweconomy.com.au/states-threaten-to-go-it-alone-on-clean-energyas-coalition-loses-plot-70162/?utm_source=RE+Daily+Newsletter\&utm_ campaign=d52c96b021-EMAIL_CAMPAIGN_2017_07_12\&utm_ medium=email\&utm_term=0_46a1943223-d52c96b021-40390089

Parkinson, G. (2018), SA Liberals vow to continue energy transition, go big in batteries: RenewEconomy. Retreived July 23, 2018, from https:// reneweconomy.com.au/sa-liberals-vow-to-continue-energy-transition-gobig-in-batteries-93367/

Peacock, F. (2016), Graph of the day - Tesla Powerwall 2 way ahead of competition on price: Renew Economy. Retreived January 10, 2017, from http:// reneweconomy.com.au/graph-of-the-day-tesla-powerwall-2-way-aheadof-competition-on-price-62928/

Reed, T. (2016), Energy prices Part 2: Why is this happening? - Ai Group Blog . Retrieved January 31, 2017 from http://blog.aigroup.com.au/energy-pricespart-2-why-is-this-happening/

RET. (2018), REC Prices. Renew. Energy Traders Aust. Retrieved October 11, 2018 from http://retaustralia.com.au/rec-prices/

Reposit Power. (2017), Battery trial to help Bruny power long weekend. Retreived August 5, 2017, from https://www.repositpower.com/media-release/brunybattery-trial/

Roy Morgan Research. (2017), Solar electric panels hot items in Queensland and South Australia. Retreived from https://www.roymorgan.com/ findings/7262-solar-energy-electric-panels-march-2017-201707061419

Saddler, H. (2017), How consumers got burned on electricity prices: It started with networks: RenewEconomy. Retreived July 23, 2018, from https:// reneweconomy.com.au/consumers-got-burned-electricity-prices-startednetworks-48000/

Simshauser, P., Laochumnanvanit, K. (2011), The price-suppression domino effect and the political economy of regulating retail electricity prices in a rising cost environment (No. 20). 
Solar Choice. (2017), Solar system prices based on live data. Retreived March 18, 2018, from https://www.solarchoice.net.au/blog/solar-power-system-price

Vorrath, S. (2017), SA rooftop solar installs surge after statewide blackout: Renew Economy. Retreived March 9, 2017, from http://reneweconomy. com.au/sa-rooftop-solar-installs-surge-statewide-blackout-87015/?utm_ source $=\mathrm{RE}+$ Daily + Newsletter\&utm_campaign $=7781616 \mathrm{c} 7 \mathrm{~d}-\mathrm{EMAIL}$ CAMPAIGN_2017_03_09\&utm_medium=email\&utm_term $=0$ _ 46a1943223-7781616c7d-40390089 